\title{
Laboratory experiments on scour around flat circular buckets for high waves and strong current at Wido Windfarm, Westsouth Sea, Korea
}

\author{
H. Kim, I. Kim, S. Lee \& T. Hong \\ Kookmin University, Seoul, Korea
}

ABSTRACT: Laboratory experiment on scour around three circular suction bucket foundations was carried out at Kookmin University basin, $0.8 \mathrm{~m}$ wide, $1 \mathrm{~m}$ deep, and $23 \mathrm{~m}$ long. The buckets form the foundations of wind power towers of Korea Westsouth Sea Windfarm. Bed material at the site is sand, and finer sand was chosen for laboratory modelling test. The strongest current of $1.03 \mathrm{~m} / \mathrm{s}$, the maximum significant wave height of $5.3 \mathrm{~m}$, and the maximum wave height of $8.1 \mathrm{~m}$ were undistortedly scaled down by 1/70 in length. Measured scour depths are all under 0.6 times the bucket diameter. Experimental results for currents have been compared with a numerical model STEP, and its modified version STEP-K. Both models over predict the scour depths around the buckets, and also predict earlier evolution of the scour compared to the laboratory measurements.

\section{INTRODUCTION}

The Korean government plans to construct the preliminary internal corroborative offshore windfarm on the westsouth sea which is near Buan-Gun, and Gochang-Gun, Jeonbuk Province, Korea, see Figure 1. The site is located $8 \mathrm{~km}$ away from Wido Island, and $10 \mathrm{~km}$ from the west coastline.

The tidal range at the site is between 5.44 and $2.54 \mathrm{~m}$, and the strongest tidal currents over both the flood and ebb tide are known to be about $1.03 \mathrm{~m} / \mathrm{s}$.

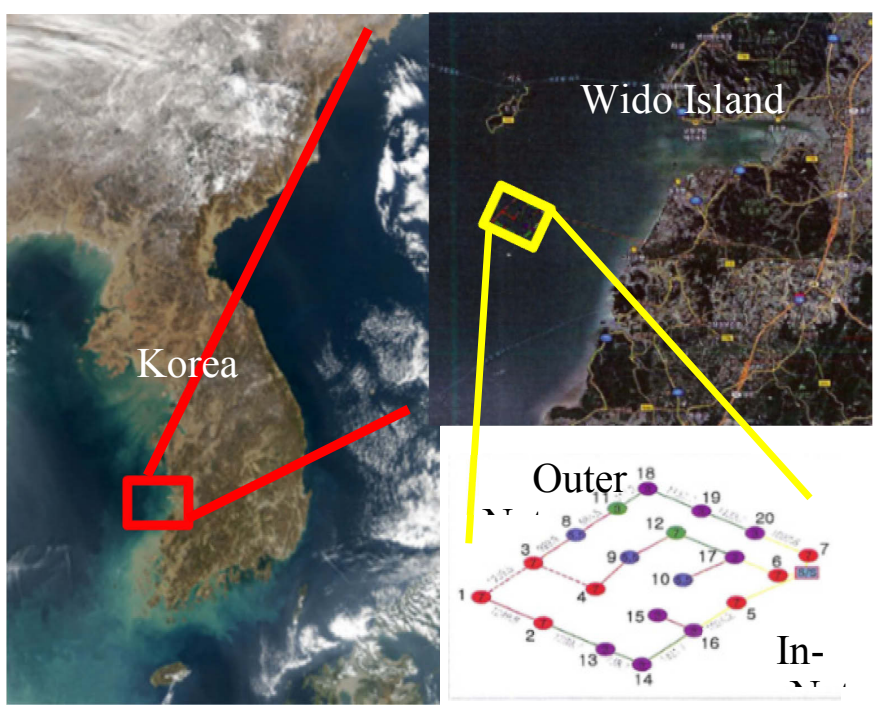

Figure 1. Wido Windfarm at Westsouth Sea, Korea.
Both tidal currents and waves are strong at the site. The average of wind velocity is $1.86 \mathrm{~m} / \mathrm{s}$, and the maximum significant wave height is $5.3 \mathrm{~m}$, and the maximum wave height in 2015 is $8.1 \mathrm{~m}$. The water depth at the site is around $9.2 \mathrm{~m}$.

The project area for the whole project including both the interarray and export cables is $292,000 \mathrm{~m}^{2}$, and the period of construction is around 36 months. The total project cost is around 370 million US dollars. A candidate foundation type for the $3 \mathrm{MW}$ turbines is a three legged bucket foundation (Lee et al. 2015), see Figure 2. The top of the buckets lies at the ground level.

Because of large diameter of the suction buckets $(7.2 \mathrm{~m})$ and the separation distance between buckets of $15.4 \mathrm{~m}$, it is important to examine the scour risk during the design stage. Prediction of the scour depth under current and waves around marine structures could be done through laboratory experiment, numerical modelling of a combination of these.

One approach might be to use CFD, which involves simulation of the detailed flow and sediment transport processes. But, this approach suffers from the complexity of representing the many parameters combined with being computationally intensive. One of the existing numerical models is STEP (Harris et al. 2010), which was successful in reproducing several field scale scour holes including under both clear water and live bed conditions.

Scour development under a steady current and waves has been studied by Høgedal \& Hald (2005), and van Rijn (2013). 


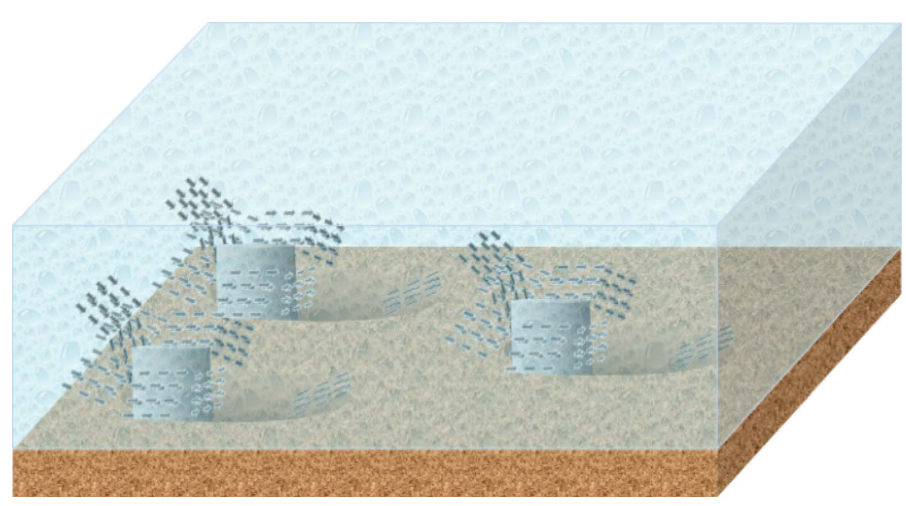

Figure 2. Scour pattern around flat buckets.

Scour development under tidal currents has been studied by Ecarameia \& May (1999), and Jensen (2006), and more recently McGovern et al. (2014) and Porter et al. (2015) but these studies focused on the variation of tidal current only.

Unsteady scour evolution exists even for steady current or steady waves. Time-evolution of scour depth under tidal current and waves has been studied by Sumer et al. (1992), Shen et al. (1965), and Harris et al. (2010). Harris et al. proposed a simple, numerical model, STEP, for predicting the time evolution of scour depth, and validated their model with several data sets. Their model is closely linked to several empirical formulas. However, they pointed out some uncertainties in their model, which require further study. For example, their model results are sensitive to the time increment chosen. In this paper, we propose a modified equation to improve this problem.

We have tried both laboratory experiment and numerical model STEP to predict scour depth at this site.

An undistorted scale is chosen to avoid uncertainly in scour reproduction. A length scale of $1 / 70$ and the Froude similarity were chosen, considering basin, bucket size, and wave generator capability.

\section{LABORATORY EXPERIMENT}

The bed material is chosen from Dean's scaling theory (Dean et al. 2006), which assimilates settling velocity of prototype sediment. The median field sediment size is $0.570 \mathrm{~mm}$. We find the settling velocity of this sediment size as:

$$
w_{p}=7.8 \times 10^{-2} \mathrm{~m} / \mathrm{s} \text { at } \mathrm{D}=0.570 \mathrm{~mm}
$$

The scale of the settling velocity is found from the Froude similarity, that is:
$w_{s}=\sqrt{L_{r}}, w_{s}=\sqrt{1 / 70}=0.12$

The scaled settling velocity should be:

$$
\begin{array}{r}
w_{s} \times w_{p}=w_{m}=0.12 \times 7.8 \times 10^{-2} \mathrm{~m} / \mathrm{s} \\
=0.936 \times 10^{-2} \mathrm{~m} / \mathrm{s}
\end{array}
$$

The sand diameter having the above settling velocity is found as $0.12 \mathrm{~mm}$ (Van Rijn 1993). A sieve test confirmed the test sand size, see Figure 3.

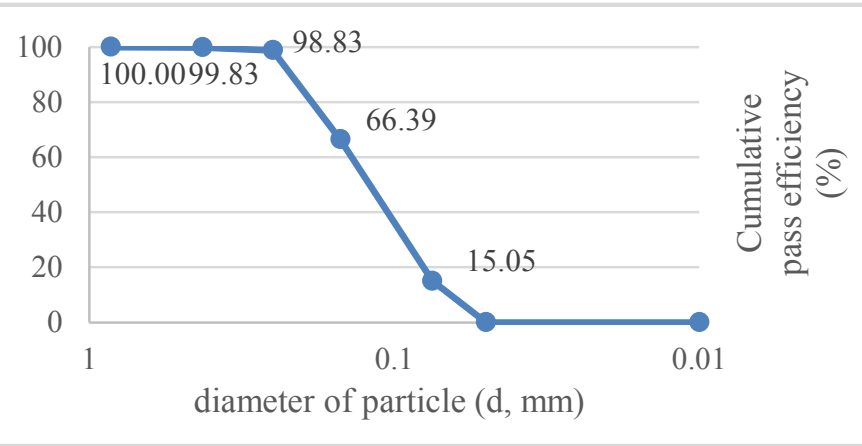

Figure 3. Sieve test result of artificial sand for laboratory experiment.

The down-scaled experimental model of the foundation for laboratory experiments is shown in Figure 4. The water basin runs both current and waves, see Figures 5 and 6.

Experiments were carried out for three extreme cases, see Table 1. If the surrounding seabed gets eroded due to extreme tidal currents or a storm, the bucket tops become exposed above the bed, and the local scour holes may develop deeper. Therefore, three more cases are planned in this experimental study, i.e. Cases 2-4. The bucket top levels are 1.5 $\mathrm{cm}$ higher than the ground level for Cases 2-4. Scour depths and shapes were measured every 15 minutes for Cases 2-4. Measured scour depths at three buckets for Cases 1 are shown in Table 2. The measured time evolution of the scour depth at the buckets is shown in Tables 3-5, and Figure 7. The contour of bucket is shown in Figure 8 which is drawn from a graphics software, Surfer 11 which converts darkness into height. The developed scour hole shape was close to symmetric.

The maximum scour depth for the three buckets for all cases was $0.6 D_{p}$, which was smaller than expected.

Ripples developed around the scour holes for all cases. Their height was between $0.5 \sim 1 \mathrm{~cm}$, which is not negligible compared to the scour depths. However, the existence of ripples has not been analyzed in depth here. 


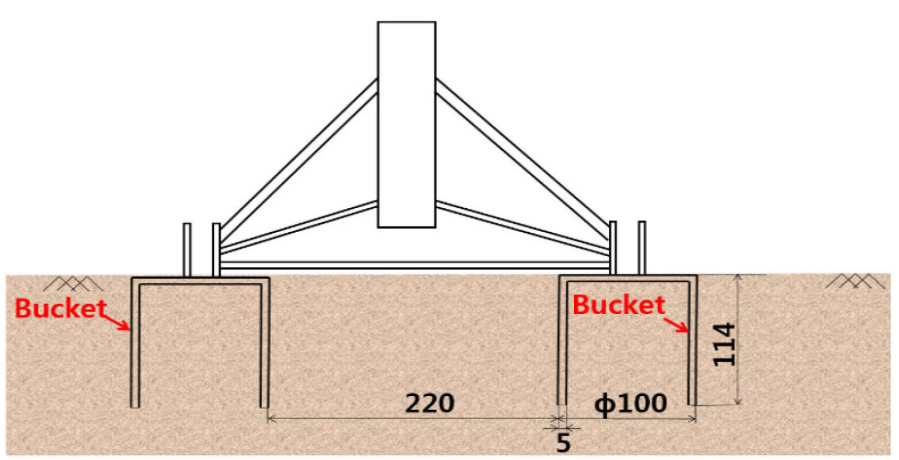

Figure 4. Model suction bucket shape.

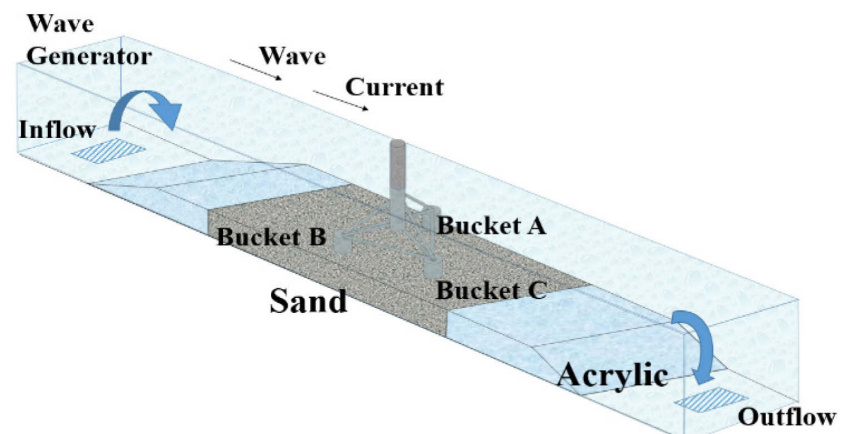

Figure 5. Numbering buckets against wave/current direction.

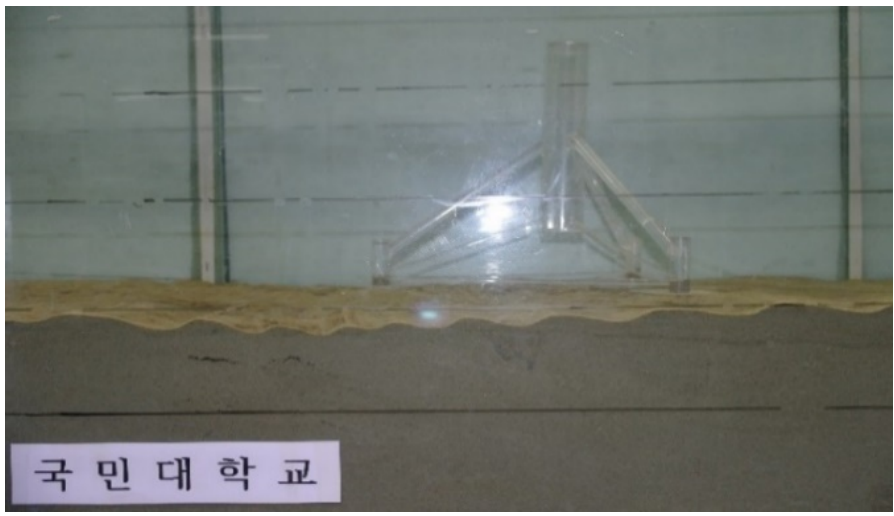

Figure 6. Photo of experimental setting.

Table 1. Test cases for current and waves.

\begin{tabular}{|c|c|c|c|c|c|}
\hline Case & Type & & Period & Wave & Current \\
\hline \multirow{2}{*}{ 1-1 } & \multirow{2}{*}{$\begin{array}{l}\text { Current } \\
\text { Only }\end{array}$} & Field & $\begin{array}{l}13.6 \\
\text { (s) }\end{array}$ & 0 & $\begin{array}{l}1.03 \\
(\mathrm{~m} / \mathrm{s})\end{array}$ \\
\hline & & Lab & $\begin{array}{l}1.63 \\
\text { (s) }\end{array}$ & 0 & $\begin{array}{l}12.31 \\
(\mathrm{~cm} / \mathrm{s})\end{array}$ \\
\hline \multirow{2}{*}{$1-2$} & \multirow{2}{*}{$\begin{array}{l}\text { Wave } \\
\text { Only }\end{array}$} & Field & 0 & $\begin{array}{l}8.1 \\
(\mathrm{~m})\end{array}$ & 0 \\
\hline & & $\mathrm{Lab}$ & 0 & $\begin{array}{l}11.6 \\
(\mathrm{~cm})\end{array}$ & 0 \\
\hline \multirow{2}{*}{$1-3$} & \multirow{2}{*}{$\begin{array}{l}\text { Current } \\
\& \text { Wave }\end{array}$} & Field & $\begin{array}{l}13.6 \\
\text { (s) }\end{array}$ & $\begin{array}{l}8.1 \\
(\mathrm{~m})\end{array}$ & $\begin{array}{l}1.03 \\
(\mathrm{~m} / \mathrm{s})\end{array}$ \\
\hline & & $\mathrm{Lab}$ & $\begin{array}{l}1.63 \\
(\mathrm{~s})\end{array}$ & $\begin{array}{l}11.6 \\
(\mathrm{~cm})\end{array}$ & $\begin{array}{l}12.31 \\
(\mathrm{~cm} / \mathrm{s})\end{array}$ \\
\hline \multirow[b]{2}{*}{ Case } & \multirow{2}{*}{\multicolumn{2}{|c|}{ Type }} & Field & Lab & \\
\hline & & & $\begin{array}{l}\text { Current } \\
(\mathrm{m} / \mathrm{s})\end{array}$ & $\begin{array}{l}\text { Current } \\
(\mathrm{cm} / \mathrm{s})\end{array}$ & \\
\hline 2 & \multirow{3}{*}{\multicolumn{2}{|c|}{ Current Only }} & 1.03 & 12.3 & \\
\hline 3 & & & 1.67 & 20 & \\
\hline 4 & & & 2.51 & 30 & \\
\hline
\end{tabular}

Table 2. Measured equilibrium scour depths at three buckets.

\begin{tabular}{llll}
\hline Bucket & Case 1-1 & Case $\mathbf{1 - 2}$ & Case $\mathbf{1 - 3}$ \\
\hline $\mathbf{A}$ & $2 \mathrm{~cm}$ & $1.5 \mathrm{~cm}$ & $4.5 \mathrm{~cm}$ \\
\hline B & $1.8 \mathrm{~cm}$ & $1.8 \mathrm{~cm}$ & $3.7 \mathrm{~cm}$ \\
\hline $\mathbf{C}$ & $2.3 \mathrm{~cm}$ & $3.8 \mathrm{~cm}$ & $5.5 \mathrm{~cm}$ \\
\hline
\end{tabular}

Table 3. Measured time evolution of scour depth for Case 2.

\begin{tabular}{lllllll}
\hline \multirow{3}{*}{ Bucket } & $\begin{array}{l}\mathbf{1 5} \\
\mathbf{m i n}\end{array}$ & $\begin{array}{l}\mathbf{3 0} \\
\mathbf{m i n}\end{array}$ & $\begin{array}{l}\mathbf{4 5} \\
\mathbf{m i n}\end{array}$ & $\begin{array}{l}\mathbf{6 0} \\
\mathbf{m i n}\end{array}$ & $\begin{array}{l}\mathbf{7 5} \\
\text { min }\end{array}$ & $\begin{array}{l}\mathbf{9 0} \\
\text { min }\end{array}$ \\
\cline { 2 - 7 } & $(\mathrm{cm})$ & $(\mathrm{cm})$ & $(\mathrm{cm})$ & $(\mathrm{cm})$ & $(\mathrm{cm})$ & $(\mathrm{cm})$ \\
\hline A & 1.7 & 2.4 & 2.9 & 3.3 & 3.4 & 3.3 \\
\hline B & 1.5 & 2.1 & 2.8 & 3.0 & 3.0 & 2.9 \\
\hline C & 2.2 & 2.9 & 3.3 & 3.7 & 3.9 & 3.8 \\
\hline
\end{tabular}

Table 4. Measured time evolution of scour depth for Case 3.

\begin{tabular}{lllllll}
\hline \multirow{2}{*}{ Bucket } & $\begin{array}{l}\mathbf{1 5} \\
\mathbf{m i n}\end{array}$ & $\begin{array}{l}\mathbf{3 0} \\
\text { min }\end{array}$ & $\begin{array}{l}\mathbf{4 5} \\
\text { min }\end{array}$ & $\begin{array}{l}\mathbf{6 0} \\
\text { min }\end{array}$ & $\begin{array}{l}\mathbf{7 5} \\
\text { min }\end{array}$ & $\begin{array}{l}\mathbf{9 0} \\
\text { min }\end{array}$ \\
\cline { 2 - 7 } & $(\mathrm{cm})$ & $(\mathrm{cm})$ & $(\mathrm{cm})$ & $(\mathrm{cm})$ & $(\mathrm{cm})$ & $(\mathrm{cm})$ \\
\hline $\mathbf{A}$ & 2.5 & 3.2 & 3.8 & 4.3 & 4.4 & 4.4 \\
\hline $\mathbf{B}$ & 1.8 & 2.5 & 3.1 & 3.5 & 3.4 & 3.5 \\
\hline $\mathrm{C}$ & 3.7 & 4.8 & 5.4 & 5.8 & 5.9 & 6.0 \\
\hline
\end{tabular}

Table 5. Measured time evolution of scour depth for Case 4.

\begin{tabular}{lllllll}
\hline \multirow{2}{*}{ Bucket } & $\begin{array}{l}\mathbf{1 5} \\
\mathbf{m i n}\end{array}$ & $\begin{array}{l}\mathbf{3 0} \\
\mathbf{m i n}\end{array}$ & $\begin{array}{l}\mathbf{4 5} \\
\mathbf{m i n}\end{array}$ & $\begin{array}{l}\mathbf{6 0} \\
\mathbf{m i n}\end{array}$ & $\begin{array}{l}\mathbf{7 5} \\
\mathbf{m i n}\end{array}$ & $\begin{array}{l}\mathbf{9 0} \\
\mathbf{m i n}\end{array}$ \\
\cline { 2 - 7 } & $(\mathrm{cm})$ & $(\mathrm{cm})$ & $(\mathrm{cm})$ & $(\mathrm{cm})$ & $(\mathrm{cm})$ & $(\mathrm{cm})$ \\
\hline A & 2.8 & 3.4 & 4.4 & 4.8 & 4.9 & 4.8 \\
\hline B & 2.5 & 3.1 & 3.6 & 4.2 & 4.3 & 4.3 \\
\hline C & 3.7 & 4.2 & 4.6 & 4.9 & 4.8 & 4.9 \\
\hline
\end{tabular}

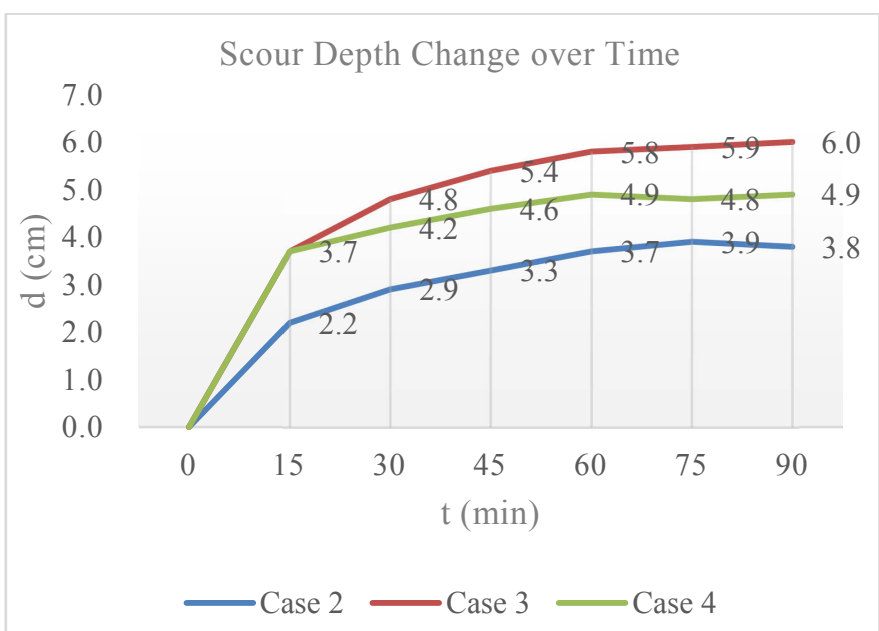

Figure 7. Measured time evolution of scour depth at Bucket C, Cases 2-4.

In all cases, the scour depths reached almost the equilibrium value at $t=1.5$ hours, which corresponds to about 13 hours at field scale, close to a semi-diurnal tidal cycle. 


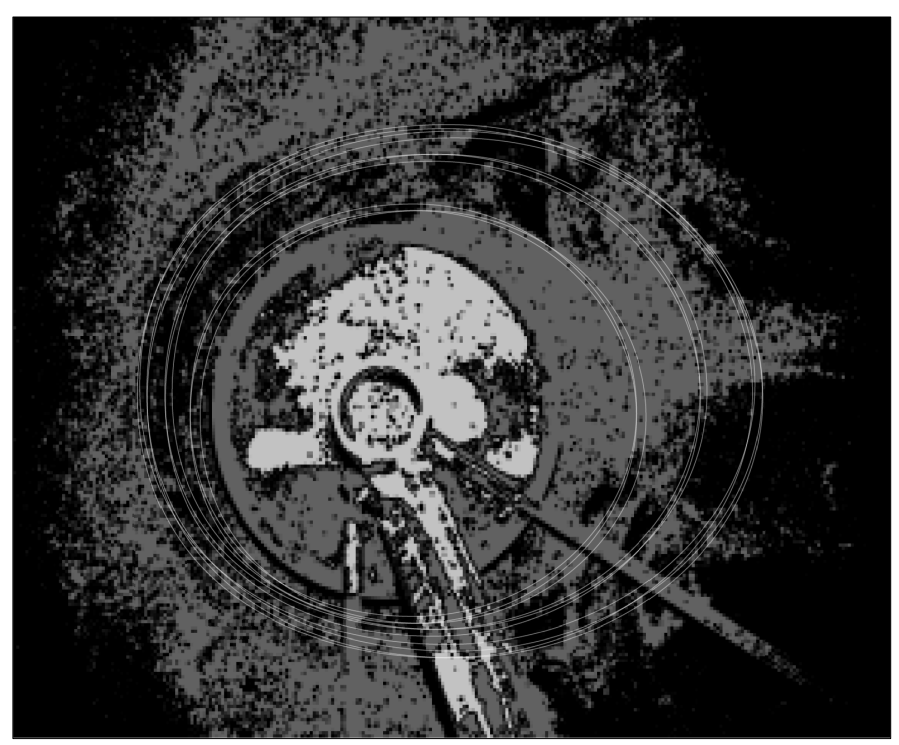

Figure 8. Contour lines of scour hole at $\mathrm{t}=60 \mathrm{~min}$, Bucket $\mathrm{C}$ for Case 3: extracted from a graphics software, SURFER 11.

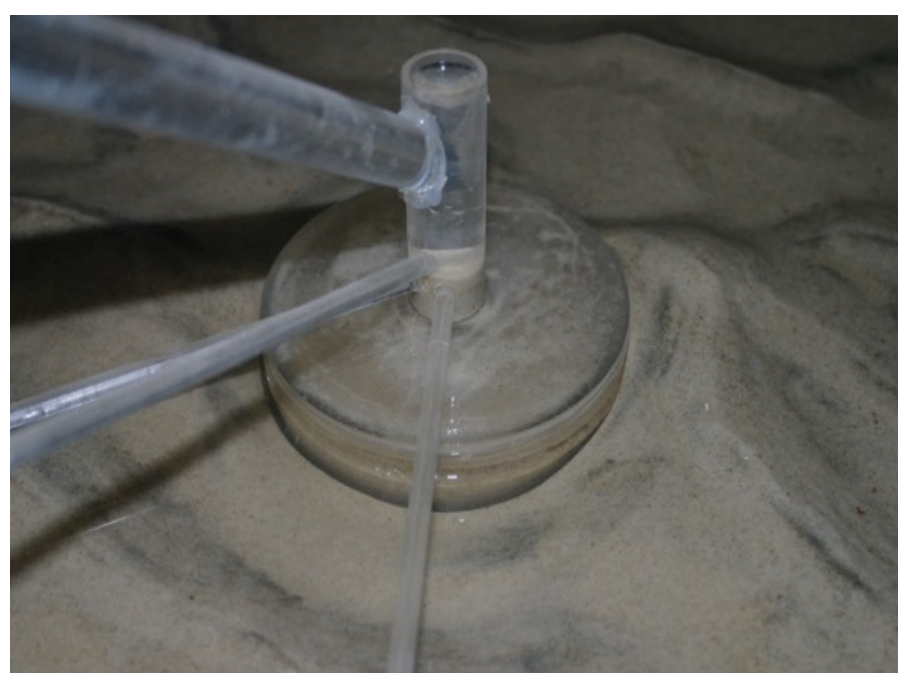

Figure 9. Measured time evolution of scour depth at $\mathrm{t}=60 \mathrm{~min}$, bucket B for Case 2.

\section{NUMERICAL MODEL}

Harris et al. (2010) proposed a numerical model, STEP, giving a detailed description of the model, and its applications. They also commented on uncertainties in their model, which need future investigation. The governing equation of STEP is

$S(t)=S_{e}\left[1-\exp \left(-\frac{t}{T_{S}}\right)^{n}\right]$

where $T_{s}=$ time-scale of the scour process; $S_{e}=$ equilibrium scour depth; and $\mathrm{n}=$ a power normally taken to be 1 (e.g. Sumer et al.). $n$ is fixed on 1 for convenience, and to avoid complexity. The above equation explains the variation of scour depth over time, as well as the equilibrium scour depth. A problem on the above equation is on choosing the time increment, because the above equation is already an integrated equation.
Therefore, we modify the above equation, and propose a differential equation corresponding to the above integrated equation, that is:

$\frac{d\left(S_{e}-S\right)}{d t}=-\frac{1}{T_{S}}\left(S_{e}-S\right)$

Taking a finite difference equation of the above equation with the non-conditionally stable CrankNicolson scheme, we have:

$S^{n+1}=S_{e}^{n+1}+\frac{S^{n}-S_{e}^{n}}{1+\frac{\Delta t}{T_{S}}}$

where $\Delta t=$ time increment. Eq. (3) is virtually the same as Eq. (1), but managing of $\Delta t$ is more flexible, i.e. any small $\Delta t$ would do. However, $\Delta t$ should not be too large to smooth out the wave effect, as proposed in the previous STEP. In order to take into account bed form roughness the current friction factor $C_{D}$ (Soulsby, 1997) is modified as:

$C_{D}=0.0204\left(\frac{20 d_{50}}{h}\right)^{0.286}$

where $d_{50}=$ median sediment diameter; and $\mathrm{h}=$ water depth.

An important parameter of the model is:

$T_{*}=\frac{\delta \theta^{-2.2}}{2000 D_{p}}$

where $T_{*}=$ non-dimensional time parameter; $\delta=$ current boundary layer thickness (water depth for currents); and $\theta=$ Shields parameter. Harris et al. have not described how to choose the above parameter $\theta$ for current/wave situations. We suggested to use $\theta_{c}+\overline{\theta_{w}}$, for $\theta$ in Eq. (4), where $\theta_{c}=$ Shields value for current, and $\overline{\theta_{w}}=$ Shields value for wave period average value. Finally, $T_{S}$ is obtained from:

$T_{S}=\frac{D_{p}^{2}}{\left\{g\{s-1\} d_{50}^{3}\right\}^{0.5}} T_{*}$

Then, the STEP solves Breusers et al.'s (2010) equilibrium scour depth equation:

$$
\begin{aligned}
S_{e} & =S_{c}=C_{B} K_{1} K_{2} K_{3} K_{4} \tanh \left(\frac{h}{D_{p}}\right) D_{p} \\
& =1.25 * 1 * 1 * 1 * 1 * \tanh \left(\frac{0.13}{0.10}\right) 0.10 \\
& =0.108(\mathrm{~m})
\end{aligned}
$$

where $S_{c}=$ current-induced scour depth; $K_{1}=$ correction factor for pile nose shape; $K_{2}=$ correction factor for angle of attack of flow; $K_{3}=$ correction factor for bed condition; $K_{4}=$ correction factor for size of bed material; and $D_{p}=$ external diameter of pile. 
STEP-K and STEP produce very similar answers for a set of steady current conditions (case3), see Figure 10. The difference comes simply from the difference between the numerical and analytical solution. Both numerical models over-predict scour depth of the given conditions at Wido Island compared to laboratory results. The speed of the evolution of the initial scour hole is also over-predicted by the two numerical models.

STEP and STEP-K will be applied to wave-only and current and wave scour scenarios for comparison with the present laboratory measurements in the future.

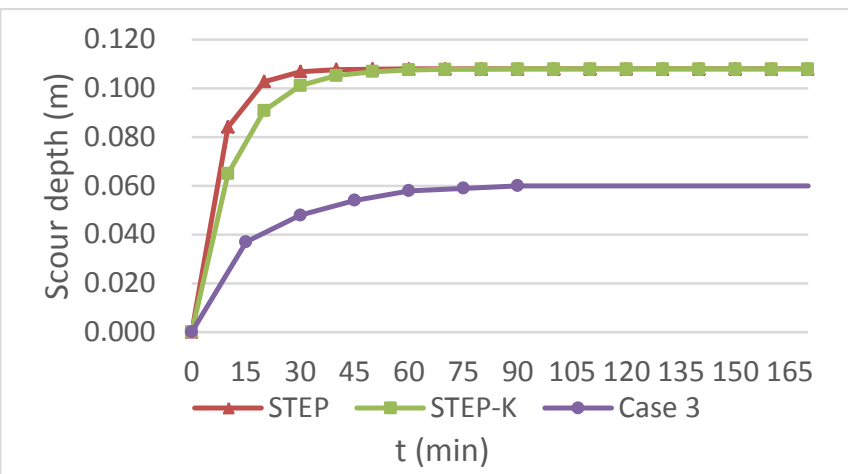

Figure 10. Measured and computed time evolution about Bucket $\mathrm{C}$ for Case 3.

\section{CONCLUSIONS}

Both the laboratory experiments and numerical modelling predict scour depths smaller than $0.6 D_{p}$. The suction bucket height is only $1.1 D_{p}$, and therefore, the laboratory and numerical modelling results suggest the foundation to be stable. However, it is too early to judge whether the suction bucket foundations are safe against local scour, because a limited number of cases were tested so far, and there are many inherent weak points in both the scaled experiments and the numerical modelling.

It is generally considered that mobile bed laboratory experiments involve scaling issues with respect to the sediment transport rate, whilst numerical modelling involves many empirical assumptions and parameters to represent the micro-scale turbulence and sediment interaction. However, the numerical modelling approach may improve further as more data sets are gathered in the future and computational power increases.

The experimental results reveals that the waveinduced scour depths are comparable with the current-induced scour depths at this site. Further, the results indicate that the group bucket has an effect on the scour depth if separation distance between buckets is not wide enough.

Important non-dimensional properties related to the local scour may include the scour depth over the structure diameter, and the scour depth over the total water depth. The effect of the water depth needs further study.

Further investigation is required for situations which combine wide area erosion and the local scour. If global bed level changes (area erosion) occurs around the bucket foundation, the safety of the foundation itself becomes more at risk.

\section{ACKNOWLEDGEMENT}

This work has been funded as a research project, "Installation and corroborative study for internal power network of ocean wind power plant", by Korea institute of Energy Technology Evaluation and Planning (KETEP) since 2015.

\section{REFERENCES}

Boon, J.H. et al. 2004. Scour behaviour and scour protection for monopile foundations of offshore wind turbines. Proc. the European Wind Energy Conference. 2004.

Eadie, R.W. \& Herbich, J.B. 1986. Scour about a single, cylindrical pile due to combined random waves and a current. Proc. Coastal Engineering: 1858-1870.

Høgedal, M. \& Hald, T. 2005. Scour assessment and design for sour for monopile foundations for offshore wind turbines. Proc. Copenhagen Offshore Wind., Copenhagen, 26-28 October 2005.

Harris, J.M. et al. 2010. The time evolution of scour around offshore structures. Proc. the. Instituition of Civil Maritime Engineering 163(1): 3-17.

Hughes, S.A. 2010. Scour and scour protection. US Army Corps of Engineers. Lecturenote.

Lee, J.-G. et al. 2013. After Trip about production site of tripod bucket foundation. Korea Geotechnical Society 29(7): 26-27 (in Korean)

Karsten, P \& Katja, W. 2012. Offshore wind energy foundation - geotextile sand-filled containers as effective scour protection systems. 6th International Conference on Scour \& Erosion 133(1): 823-830.

McGovern, D.J., Ilic, S., Folkard, A.M., McLelland, J. and Murphy, B.J. (2014). Time development of scour around a cylinder in simulated tidal currents. J. of Hydr. Engng., 140(6), 04014014

Nielsen, A.W. 2012. Scour protection of offshore wind farms. DTU Mechanical Engineering.

Porter K.E., Simons, R.R. and Harris, J.M. (2015). Laboratory investigation of scour development through a spring-neap tidal cycle. In: Scour and Erosion Proc. 7th Int. Conf. on Scour and Erosion. The University of Western Australia, 24 December. 2014. (eds.) Cheng. L., Draper, S. and An, H., CRC Press, p. 667 - 677

Rudolph, D. 2010. Scour \& scour protection; Deltares.

Van Rijn, L. 1993. Principles of sediment transport in rivers, estuaries and coastal seas. Amsterdam: Aqua Publications.

Van Rijn, L. 2013. Local scour near structures. LeovanRIJNSEDIMENT Co. 